\title{
LEVELS OF MACRO- AND MICROELEMENTS IN BLOOD PLASMA OF LATE-PREGNANT COWS AND THEIR FOETUSES
}

\author{
V. DVOŘ́K, J. BOUDA, J. DOUBEK \\ Department of Diagnostics, Therapy and Prophylaxis of Animal Diseases, \\ University of Veterinary Science, 61242 Brno
}

Dedicated to the 50th birthday of Prof. MVDr. P. Jagoš, CSc.

Received February 12, 1980

\begin{abstract}
Dvořák V., J. Bouda, J. Doubek: Levels of Macro- and Microelements in Blood Plasma of Late-pregnant Cows and Their Foetuses. Acta vet. Brno, 49, 1980: 199-204.

When examining plasma of 20 late-pregnant cows and their foetuses delivered by Caesarean section following levels of macro- and micro- elements in dams and their foetuses, resp., were found using photometry and atomic absorption spectrophotometry: plasmatic sodium $147.12 \pm 6.56$ and $148.37 \pm 9.54 \mathrm{mmol} / \mathrm{l}$; potassium $4.25 \pm 0.59$ and $4.37 \pm 0.51 \mathrm{mmol} / \mathrm{l}$; calcium $2.49 \pm 0.32$ and $3.0 \pm 0.25 \mathrm{mmol} / \mathrm{l}$; magnesium $0.87 \pm 0,12$ and $0.94 \pm 0.12 \mathrm{mmol} / \mathrm{l}$; inorganic phosphorus $2.02 \pm 0.89$ and $2.09 \pm 0.89 \mathrm{mmol} / \mathrm{l}$; zinc $30.38 \pm 32.23$ and $28.30 \pm 24.03 \mu \mathrm{mol} / \mathrm{l}$, iron $24.21 \pm$ \pm 7.69 and $42.22 \pm 19.05 \mu \mathrm{mol} / \mathrm{l}$, copper $13.54 \pm 5.76$ and $6.62 \pm 4.81 \mu \mathrm{mol} / \mathrm{l}$.

Higher level of plasmatic sodium in foetuses when compared with their dams was found in all foetuses; levels of potassium, calcium, magnesium, zinc and iron were found higher in $73 \%, 93 \%, 68 \%, 55 \%$ and $72 \%$, resp. In $77 \%$ of foetuses the copper level was observed to be lower than that in cows. The evaluation by t-test revealed a statistically highly significant difference in favour of foetuses in the case of plasmatic calcium and iron while copper levels were higher in cows. As far as other followed elements are concerned the evaluated differences were found to be statistically non-significant.
\end{abstract}

Late-pregnant cows, foetus, macroelements, microelements.

Uniform and undisturbed intrauterine development of foetus is of paramount importance for the birth of a viable and resistant individual. In this connection last $2-3$ months of gravidity are extremely critical in cattle. The following detrimental factors may negatively influence pregnant breeding cows, and therefore the foetus; qualitatively not fully valued feed ration, shortened dry period and a number of health disturbances (diarrhea, anemia, hepatodystrophy, ketoses, mastitis, acid-base balance disturbances, intrauterine infections, etc.) (Slanina et. al 1977). Increasing performance of dairy cows represents higher demands on the organism, influencing significantly metabolic processes. The disturbance of the latter in pregnant breeding cows has a negative effect on the foetus development and leads to a weak, insuficiently developed foetus with high morbidity and mortality (Terechina et. al. 1963).

Calves suffering from health disturbances after birth differ from healthy animals by biochemical findings already at birth and probably even during their foetal life (Cabello, Michel 1977). Those and similar considerations were the reason why a number of authors have studied the foetal metabolism and the level of its regulation and the interrelations between a dam and foetus. Dzenite (1975) has followed contents of trace elements in blood, liver, and muscles in foetuses and dams as well as the contents of these elements in ovaries, placenta and uterus wall in pregnant cows. Ciradze (1967), Baetz et al. (1976), Frerking (1979), Barlet et al. (1979), Roux et al. (1979) have reported on metabolism in bovine foetuses, Slanina et al. (1971), Hajdu et. al. (1977) 
have been interested in the mutual relation of dam and foetus. Care et al. (1979) examined transplacental magnesium fluxes between the ewe and foetus.

The purpose of our work was to determine the levels of plasma minerals and to find relations between the mother and foetus during the last six weeks prior to the expected date of delivery.

\section{Materials and Methods}

During winter season 20 late-pregnant cows of Bohemian Spotted breed and their foetuses, delivered by a Caesarean section during the last six weeks of gravidity, were followed at the Department of Farm Animal Reproduction and Surgery at the University of Veterinary Sciences. Prior to operation the cows were clinically examined in order to exclude animals with deviations from good health. Cow blood samples were collected from v. jugularis immediately prior to Caesarean section; as a rule plasma was analysed during 24 hours after the sampling. Heparin was as an anticoagulant agent for blood treatment. In the case of foetuses blood samples were taken from a. carotis immediately after the delivery and treated in the same way as in cows. Plasmatic inorganic phosphorus was determined using Bio-La-Tests (Lachema Brno). The determination of plasmatic $\mathrm{Na}, \mathrm{K}, \mathrm{Ca}, \mathrm{Mg}, \mathrm{Zn}, \mathrm{Fe}$ and $\mathrm{Cu}$ levels was carried out using the method of atomic absorption spectrophotometry.

\section{Results and Discussion}

The mean body mass of foetuses up to the age of 34 and 36 weeks was found to be $31.0 \pm 4.2$ and $32.8 \pm 9.3 \mathrm{~kg}$, resp. The determined mean values of plasma sodium, potassium, calcium, magnesium, inorganic phosphorus, zinc, iron and copper in cows and their foetuses are summarized in Table 1.

Table 1

Mean levels of macro- and microelements in the plasma of dams and their foetuses

\begin{tabular}{|c|c|c|c|c|c|c|c|c|}
\hline & $\underset{\mathrm{mmol} / 1}{\mathrm{Na}}$ & $\underset{\mathrm{mmol} / \mathbf{1}}{\mathrm{K}}$ & $\underset{\mathrm{mmol} / 1}{\mathrm{Ca}}$ & $\underset{\mathrm{mmol} / 1}{\mathrm{Mg}}$ & $\underset{\mathrm{mmol} / \mathbf{1}}{\text { Inorg. P }}$ & $\underset{\mu \mathrm{mol} / 1}{\mathrm{Zn}}$ & $\underset{\mu \mathrm{mol} / 1}{\mathrm{Fe}}$ & $\underset{\mu \mathrm{mol} / 1}{\mathrm{Cu}}$ \\
\hline $\begin{array}{l}\text { Cows } \\
\text { Foetuses } \\
\text { Statistical }\end{array}$ & $\begin{array}{l}147.12 \\
\pm 6.56 \\
148.37 \\
\pm 9.54\end{array}$ & $\begin{array}{r}4.25 \\
\pm 0.59 \\
4.37 \\
\pm 0.51\end{array}$ & $\begin{array}{r}2.49 \\
\pm 0.32 \\
3.00 \\
\pm 0.25\end{array}$ & $\begin{array}{r}0.87 \\
\pm 0.12 \\
0.94 \\
\pm 0.12\end{array}$ & $\begin{array}{r}2.02 \\
\pm 0.89 \\
2.09 \\
\pm 0.89\end{array}$ & $\begin{array}{r}30.38 \\
\pm 32.23 \\
28.30 \\
\pm 24.03\end{array}$ & $\begin{array}{r}24.21 \\
\pm 7.69 \\
42.22 \\
\pm 19.05\end{array}$ & $\begin{array}{r}13.54 \\
\pm 5.76 \\
6.62 \\
\pm 4.81\end{array}$ \\
\hline significance & $\mathbf{P}=\mathbf{0}$ & $\mathbf{P}=0$ & $\mathbf{P}<0.01$ & $\mathbf{P}=0$ & $0=P$ & $\mathbf{P}=0$ & $\mathrm{P}<0.01$ & $\mathbf{P}<0.01$ \\
\hline
\end{tabular}

The concentration of plasmatic sodium in cows in the 9th month of gravidity was reported by Lane et al. (1968). The authors found the mean value of $281.0 \pm$ $\pm 2.62 \mathrm{mg} / 100 \mathrm{ml}(122.22 \pm 1.13 \mathrm{mmol} / \mathrm{l})$ while Frerking (1979) measured $333.0 \pm 10.5 \mathrm{mg} / 100 \mathrm{ml}(144.85 \pm 4.56 \mathrm{mmol} / \mathrm{l})$. If we consider the value of $136-148 \mathrm{mmol} / 1$ (Jagoš et al. 1977) as a reference value for $\mathrm{Na}$ in blood plasma in cows then values within this range were found in ten cows, values higher than the upper limit of this reference range in six cows and values below the lower limit of the reference range in four cows. As far as the foetuses are concerned the cmount of plasmatic sodium was slightly higher than that in their dams, being in average $148.37 \pm 9.54 \mathrm{mmol} / \mathrm{l}$. Wilson et al. (1977a, b) arrived at the same conclusion which is, however, in contradiction with the finding of Frerking (1979) who found a value of $322.0 \pm 14.3 \mathrm{mg} \mathrm{Na} / 100 \mathrm{ml}(140.07 \pm 6.22 \mathrm{mmol} / \mathrm{l})$ in the blood of nine months' bovine foetus which was significantly lower level than in mothers. Baetz et al. (1976) found a value $146.9 \pm 0.8 \mathrm{mEq} \mathrm{Na} / 1$ in serum of bovine foetuses, Altman and Dittmer (1974) reported values $142 \pm$ $\pm 6 \mathrm{mEq} / \mathrm{l}$. These sodium levels are, in comparison with our data, somewhat lower. Dalton (1967) observed in newborn calves a mean value of plasmatic 
sodium as being $145 \pm 7.6 \mathrm{mEq} / 1$. In one of our followed cows the highly increased level of plasmatic sodium (164 mmol/l) correlated with a high content of plasmatic sodium in foetus $(174 \mathrm{~mol} / \mathrm{l})$. In this cow a higher amount of plasmatic potassium $(5.3 \mathrm{mmol} / \mathrm{l})$ was also found, correlating as well with higher plasmatic potassium level $(5.4 \mathrm{mmol} / \mathrm{l})$ in her foetus.

Plasmatic potassium levels within the reference range of $3.9-5.2 \mathrm{mmol} / 1$ (Jagoš et al. 1977) were determined in 15 cows, in four cows this level was over and in one cow slightly below this reference range. Frerking (1979) found the plasmatic potassium value in late-pregnant cows and their foetuses to be $17.2 \pm$ $\pm 1.9 \mathrm{mg} / 100 \mathrm{ml}(4.38 \pm 0.48 \mathrm{mmol} / 1)$ and $19.4 \pm 5.7 \mathrm{mg} / 100 \mathrm{ml}(4.94 \pm 1.45$ $\mathrm{mmol} / \mathrm{l})$, resp., this value being considerably higher than the values found by us $(4.37 \pm 0.51 \mathrm{mmol} / \mathrm{l})$. Dalton (1967) determined an average potassium value of $4.5 \pm 0.5 \mathrm{mEq}$ per one litre of plasma of newborn calves. In our examination the mean level of plasmatic potassium in foetuses was found to be slightly higher than in their dams, this finding being supported by Wilson et al. (1977a, b) and Frerking (1979). When comparing plasmatic potassium levels in foetuses and their dams higher level was found in 11 foetuses, i.e. in $73 \%$.

In cows in late pregnancy hypocalcemia and hypophosphatemia often occur. In average $5 \mathrm{~g}$ of calcium is daily transferred from the maternal to fetal organism (Kolb 1979). This transplacental calcium flux is an active process which is directed against the concentration gradient (Care et al. 1979; Frerking 1979). During the last months of pregnancy the foetus is able to regulate its calcemia independently of dam (Barlet et al. 1976). E. g. a rapid and substantial increase in maternal plasmatic calcium in pregnant cow can be induced by a calcium infusion without increasing the fetal level of plasmatic calcium. The calcium level in bovine fetal plasma could be influenced by application of sterolglycosid 1,2, 5-dihydroxycholecalciferol contained in Solanum glaucophyllum. The mechanism of this biologically active metabolite of vitamin $\mathrm{D}$ could be explained either by stimulation of transplacental calcium and phosphorus fluxes from dam to foetus or by its own transfer through placenta to foetus where it induces a bone resorption or raises interstitial calcium absorption from fetal intestine (Roux et al. 1979; Barlet et al. 1979).

The plasmatic calcium level in the reference range $2.25-3.0 \mathrm{mmol} / 1$ (Jagoš et al. 1977) was determined in 14 cows. Following values of plasmatic calcium in cows in late pregnancy have been found by various authors: $9.9-10.4 \mathrm{mg} / 100 \mathrm{ml}$ $(2.47-2.6 \mathrm{mmol} / \mathrm{l}$ ) (Altman and Dittmer 1974); $7.3 \pm 0.13 \mathrm{mg} / 100 \mathrm{ml}$ $(1.82 \pm 0.03 \mathrm{mmol} / \mathrm{l})$ (Lane et al. 1968); $9.5 \pm 0.5 \mathrm{mg} / 100 \mathrm{ml}(2.37 \pm 0.12 \mathrm{mmol} /$ 1) (Frerking 1979). The value determined in cows and their foetuses by us was $2.49 \pm 0.32 \mathrm{mmol} / 1$ and $3.0 \pm 0.25 \mathrm{mmol} / 1$, resp. When comparing our results with the findings of Frerking (1979) $(12.8 \pm 1,0 \mathrm{mg} / 100 \mathrm{ml} ; 3.2 \pm 0.25$ $\mathrm{mmol} / \mathrm{l}$ of plasma calcium in foetus) the values found by us were substantially higher. By statistical evaluation using the t-test a highly significant difference in favour of foetuses was observed. Slanina et al. (1971), Wilson et al. (1977a, b) and Frerking (1979) arrived at the same conclusion. In $93 \%$ of followed foetuses the absolute level of plasmatic calcium was higher than in their dams.

The magnesium levels in blood plasma were, in comparison with values reported $(0.78-1.06 \mathrm{mmol} / \mathrm{l})$ by Jagoš et al. (1977), within this reference range in 14 cows, while in two cows the values were lower. The plasmatic magnesium level of foetuses of these two dams was also lowered, reaching the lower limit of this reference range $(0.82 \mathrm{mmol} / \mathrm{l})$. Lane et al. (1968) found a somewhat higher 
magnesium level in cows in the ninth month of pregnancy when compared with our mean value. Altman and Dittmer (1974) reported a value of $2.19 \mathrm{mg} / 100 \mathrm{ml}$ $(0.90 \mathrm{mmol} / \mathrm{l})$ found 12 hours prior to parturition.

Baetz et al. (1976) determined $3.1 \pm 0.1 \mathrm{mg}$ of magnesium in $100 \mathrm{ml}(1.27 \pm$ $\pm 0.04 \mathrm{mmol} / \mathrm{l})$ in bovine fetal blood plasma, Frerking (1979) $2.6 \pm 1.3 \mathrm{mg} / 100$ $\mathrm{ml}(1.06 \pm 0.53 \mathrm{mmol} / \mathrm{l})$. In our experiment the mean value of plasmatic magnesium, being $0.94 \pm 0.12$, was slightly higher in foetuses than in their dams. A number of other authors arrived at the same conclusion: Slanina et al. (1971), Hajdu et al. (1977), Wilson et al. (1977b), Frerking (1979).

In agreement with other authors (Slanina et al. 1971; Hajdu et al. 1977; Wilson et al. 1977a, b; Frerking 1979) we determined a higher mean level of inorganic phosphorus in foetuses $(2.08 \pm 0.53 \mathrm{mmol} / \mathrm{l})$ as compared with the values of pregnant cows $(2.02 \pm 0.89 \mathrm{mmol} / \mathrm{l})$. The values of inorganic phosphorus found in cows in ninth month of pregnancy reported by Lane (1968) (6.3 土 $\pm 0.12 \mathrm{mg} / 100 \mathrm{ml} ; 2.03 \pm 0.04 \mathrm{mmol} / \mathrm{l})$, and Frerking (1979) $(6.1 \pm 0.9 \mathrm{mg} /$ $/ 100 \mathrm{ml} ; 1.97 \pm 0.29 \mathrm{mmol} / \mathrm{l})$ are almost identical with values we observed. Baetz et al. (1976) report a mean inorganic phosphorus level of $2.20 \pm 0.06 \mathrm{mmol} / \mathrm{l}$ for bovine fetal serum; in newborn calves this value was $5.51 \mathrm{mg} / 100 \mathrm{ml}(1.8$ $\mathrm{mmol} / \mathrm{l})$ and $8.57 \pm 0.25 \mathrm{mg} / 100 \mathrm{ml}(2.76 \pm 0.08 \mathrm{mmol} / \mathrm{l})$ as found by $\mathrm{Hajdu}$ et al. (1977) and McMurray et al. (1978), resp.

The plasmatic zinc value in ruminants remains relatively constant till the period prior to parturition, then decreases not only in cattle (Dufty et al. 1977) but also in sheep (Apgar, Travis 1979). If we take into consideration a reference range of cow plasmatic zinc $(12.2-45.9 \mu \mathrm{mol} / \mathrm{l})$ (Jagoš et al. 1977) then dairy cows were included in this range, three were below and five over this range. In $55 \%$ of foetuses the zinc level in plasma was higher than that in their dams, this difference being statistically significant in two cases. Dufty et al. (1977) arrived at a similar conclusion, finding approximately doubled concentrations of plasmatic zinc in newborn calves than in their dams. Abnormally increased levels of plasmatic zinc in three of our cows correlated in two cases with a considerably increased level in their foetuses. The average plasmatic zinc level of foetuses was, nevertheless, only non-significantly lower as compared with cows $(28.30 \pm$ $\pm 24.03 \mu \mathrm{mol} / 1$.)

The plasmatic iron level was within the reference range of $21.5-35.8 \mu \mathrm{mol} / 1$ (J agoš et al. 1977) in 9 cows, lowered in eight and increased in three cows. In $72 \%$ of foetuses the observed level of plasmatic iron was higher than that in their dams. In nine of these 13 cases the difference was statistically significant. The average value of plasmatic iron was $24.21 \pm 7.69 \mu \mathrm{mol} / \mathrm{l}$ and $42.22 \pm 19.05$ $\mu \mathrm{mol} / 1$ in dams and foetuses, resp. Statistical evaluation using the t-test revealed a highly significant difference in iron level in favour of foetuses.

The plasmatic copper levels were in the reference range of $12.6-18.9 \mu \mathrm{mol} / 1$ (Jagoš et al. 1977) in 11 cows and reached in all breeding cows an average value of $13.54 \pm 5.76 \mu \mathrm{mol}$ ). Slightly higher copper level was determined in one animal, a rather pronounced lower level (below the range) in eight cases. It is noteworthy that in three cases of significant decrease of maternal copper value - about $4.7 \mu \mathrm{mol} / 1$ - the values found in their foetuses exceeded the limit of $15.7 \mu \mathrm{mol} / 1$. In $77 \%$ of foetuses the copper level was lower than that of their dams. The average level of plasmatic fetal copper was found to be $6.62 \pm 4.81 \mu \mathrm{mol} / 1$. Statistical evaluation using the t-test revealed a highly significant difference in plasmatic copper in favour of cows. 


\section{Hladiny plazmatických makroelementů a stopových prvků u vysokobřezích krav a jejich fetů}

Při vyšetřování plasmy dvaceti vysokobřezích krav a jejich fetủ vybavených císařským řezem byla fotometricky a atomovou absorpční spektrofotometrií nalezena v zimním období následující množství makroelementů a stopových prvků u matek, resp. jejich plodů: plazmatický sodík 147,12 $\pm 6,56-148,37 \pm 9,54$ $\mathrm{mmol} / \mathrm{l}$; draslík 4,25 $\pm 0,59-4,37 \pm 0,51 \mathrm{mmol} / \mathrm{l}$; vápník $2,49 \pm 0,32-3,0 \pm$ $\pm 0,25 \mathrm{mmol} / 1$; hořč́k $0,87 \pm 0,12-0,94 \pm 0,12 \mathrm{mmol} / 1$; anorganický fosfor $2,02 \pm 0,89-2,09 \pm 0,89 \mathrm{mmol} / \mathrm{l} ;$ zinek $30,38 \pm 32,23-28,30 \pm 24,03 \mu \mathrm{mol} / \mathrm{l}$, železo $24,21 \pm 7,69-42,22 \pm 19,05 \mu \mathrm{mol} / 1 ;$ měd $13,54 \pm 5,76-6,62 \pm 4,81$ $\mu \mathrm{mol} / 1$. Absolutně vyšší hladina plazmatického sodíku fetů při srovnání s matkou byla nalezena u všech plodů, draslíku u $73 \%$, vápníku u $93 \%$, hořčíku u $68 \%$, zinku u $55 \%$ a železa u $72 \%$ plodů. U $77 \%$ fetů byla zjištěná hladina mědi nižší oproti kravám. Při zhodnocení t-testem byl statisticky vysoce významný rozdíl ve prospěch fetů zaznamenán u plazmatického vápníku a železa, ve prospěch plemenic u mědi. $U$ ostatních sledovaných minerálií byly zjištěné rozdíly statisticky nevýznamné.

\section{Уровни плазматических макроэлементов и микроэлементов у коров на высокой стадии беременности и их зародышей}

В ходе исследования плазмы двадцати коров на высокой стадии беременности и их зародышей, изъятых кесаревым сечением, фотометрически и ядерной абсорбционной спектрофотометрией были установлены в зимний период следующие макроэлементы и микроэлементы у коров или их зародышей: плазматический натрий $147,12 \pm 6,56-148,37 \pm 9,54$ ммоль/л; калий $4,25 \pm 0,59-4,37 \pm 0,51$ ммоль/л; кальций $2,49 \pm 0,32-3,0 \pm 0,25$ ммоль/л; магний $0,87 \pm 0,12-0,94 \pm 0,12$ ммоль/л; неорганический фосфор $2,02 \pm 0,89-2,09 \pm 0,89$ ммоль/л; цинк $30,38 \pm 32,23-28,30 \pm 24,03$ мкмоль/л; железо 24,21 $\pm 7,69-42,22 \pm 19,05$ мкмоль/л: медь $13,54 \pm 5,76$ - 6,62 $\pm 4,81$ мкмоль/л. Абсолютно более высокий уровень плазматического натрия зародышей по сравнению с коровой был выявлен у всех зародышей, калия у $73 \%$, кальция у $93 \%$, магния у $68 \%$, цинка у $55 \%$ и железа у $72 \%$ зародышей. В случае $77 \%$ зародышей был установлен уровень меди по сравнению с коровами ниже. В ходе оценки т-тестом отличалась высокой статистической значимостью разность в пользу зародышей у плазматического кальция и железа, в пользу племенных маток у меди. У остальных исследуемых минеральных веществ выявленная разница не отличалась статистической значимостью.

\section{References}

ALTMAN, P. L. - DITTMER, D. S.: Biology Data Book. Second Ed. Vol. III. Federation of American Societies for Experimental Biology, Bethesda, USA, 1974; 2123.

APGAR, J. - TRAVIS, H. F.: Effect of a low zinc diet on the ewe during pregnancy and lactation. J. Amin. Sci., 48, 1979: 1234-1238.

BAETZ, A. L. - HUBBERT, W. T. - GRAHAM, C.K.: Changes of biochemical constituents in bovine fetal fluids with gestational age. Am. J. vet. Res., 37, 1976: 1047-1052. 
BARLET, J. P. - GAREL, J. M. - LEFAIVRE, J. - DARDILLAT, C.: Régulation endocrinienne de la calcémie foetale chez la vache et la brebis. J. Physiol., Paris, 71, 1976: 34 A.

BARLET, J. P. - DAVICCO, M. J. - LEFAIVRE, J. - CARILlO, B. J.: Fetal blood calcium response to maternal hypercalcemia induced in the cow by calcium infusion or by Solanum glaucophyllum ingestion. Horm. metab. Res., 11, 1979: 57-60.

CABELLO, G. - MICHEL, M. C.: Composition du plasma sanguin (calcium, phosphore, magnésium, protéines) pendant la periode neonatale chez le veau, influence de l'etat de sante. Annls Rech. vét., 8, 1977: 203-211.

CARE, A. D. - PICKARD, D. W. - WEATHERLEY, A. - APPLEBY, D.: Measurement of transplacental magnesium fluxes in the sheep. Res. vet. Sci., 27, 1979: 121-122.

ČIRADZE, V.: Soderžanie kalcija i fosfora v krovi korov i ploda. Veterinarija, 44, 1967: 96.

DALTON, R. G.: Variations in calf plasma composition with age. Br. vet. J., 123, 1967: 48-52.

DUFTY, J.H. - BINGLEY, J. B. - COVE, L. Y.: The plasma zinc concentration of nonpregnant and parturient Hereford cattle. Aust. vet. J., 53, 1977: 519-522.

DZENITE, A. JA.: Mineralnyje rezervy $\mathrm{v}$ organizme korov vo vremja beremennosti. Vsasyvanie i obmen pitatelnych veščestv v organizme životnych. Zinatne, Riga, 1975: 173-177.

FRERKING, H.: Mineralstoffgehalte im Blutserum von Rinderfeten und deren Mütter während der zweiten Hälfte der Tragezeit. Dte tierärztl. Wschr., 86, 1979: 265-267.

HAJDU, Š. - BLAHO, R. - HEČKO, R.: Štúdium humorálného imunitného systému hovädzieho dobytka v postnatálnom období. II. časti. Imunoprofylaxia, Př́roda, Bratislava, 4, 1977: $45-64$.

JAGOŠ, P. - ILLEK, J. - BOUDA, J. - DVOŘÁK, R. - HOFÍREK, B. - LEBEDA, M. - MACHÝČEK, V. - ZÝKA, V. - ZIMA, L.: Metodika provádění a interpretace metabolického testu u skotu. Ústav veterinární osvěty Pardubice. Veterinární péče ve velkochovech skotu, 3, 1977: 33.

KOLB, E.: Neuere ernährungsbiochemische Erkenntnisse zur Entstehung und Verhütung der Gebärparese. Mh. VetMed., 34, 1979: 65-69.

LANE, A. G. - CAMPBELL, J. R. - KRAUSE, G. F.: Blood mineral composition in ruminants. J. Anim. Sci., 27, 1968: 766-770.

McMURRAY, C. H. - LOGAN, E. F. - McPARLAND, P. J. - McRORY, F. J. = O'NEIL, D. G.: Sequential changes in some blood components in the normal neonatal calf. Br. vet. J., 134, 1978: $590-597$.

ROUX, R. - DAVICCO, M. J. - CARILLO, B.I. - BARLET, J. P.: Solanum glaucophyllum in pregnant cows. Effect on colostrum mineral composition and plasma calcium and phosphorus levels in dams and newborn calves. Annls Biol. anim. Biochim. Biophys., 19, 1979: 91-101.

SLANINA, L. - SLABEJ, J. - SOKOL, J.: Študium niektorých vzájomných vztahov u dojníc a ich novorodených teliec. I. Hodnoty alkalickej rezervy krvnej plazmy a krvných elementov. Veterinářství, 21, 1971: 156-159.

SLANINA, L. et al.: Zdravie a chorobnost teliat v priemyselnej produkcii. Príroda, Bratislava, 1977: 335 .

TERECHINA, M. T. - BOBYLEVA, Z. I. - SIPKO, I. I. - LJUBIMOV, JU. A. - KOTENKO, N. A. - ZIBOROVA, V. P.: Narušenije obmena veščestv u korov i charakteristika dispepsii u teljat. Veterinarija, 40, 1963: $31-34$.

WILSON, G. D. A. - HUNTER, J. T. - DERRICK, G. H. - AITKEN, W. M. - KRONFELD, D. S.: Fetal and maternal mineral concentration in dairy cattle during late pregnancy. J. Dairy Sci., 60, 1977a: $935-941$.

WILSON, G. D. A. - HUNTER, J. T. - DERICK, G. H. - AITKEN, W. M. - KRONFELD, D. S.: Fetal and maternal plasma electrolytes, blood gases and $\mathrm{pH}$ in dairy cows during late gestation. J. Dairy Sci., 60, 1977b: 1110-1116. 